\title{
PRODUCTION AND BIOLOGICAL ACTIVITY OF MARCELLOMYCIN, AN ANTITUMOR ANTHRACYCLINE ANTIBIOTIC, AND TAXONOMY OF THE PRODUCING ORGANISM
}

\author{
J. A. Bush and W. T. Bradner \\ Bristol Laboratories, Division of Bristol-Myers Company, \\ Syracuse, New York 13201, U.S. A. \\ K. TOMITA \\ Bristol-Banyu Research Institute, Ltd., \\ Meguro, Tokyo, Japan \\ (Received for publication May 24, 1982)
}

\begin{abstract}
An actinomycete, isolated from a soil sample from Ontario, Canada, was studied taxonomically and named Actinosporangium bohemicum sp. nov. strain C-36,145. This strain was found to produce a complex mixture of $\varepsilon$-pyrromycinone glycosides having antitumor properties. Marcellomycin, a member of this complex, was selected for further study. Conditions for production of this antibiotic were developed in flask studies and scaled-up to the 3,000-liter fermentor stage.
\end{abstract}

A microorganism was isolated from a soil sample collected in Ontario, Canada during a screening program for the isolation of novel antitumor agents. This organism, designated strain C-36,145, was cultured in shake-flasks and samples were tested for in vivo antitumor activity. Tumor inhibitory effects were observed first with Walker 256 carcinosarcoma $^{1)}$ carried as a solid intramuscular implant.

With further investigation activity against transplanted mouse leukemias P388 ${ }^{2}$ and L1210 ${ }^{3)}$ was obtained with crude culture extracts. The antitumor active products of strain C-36,145 were found to be glycosides of $\varepsilon$-pyrromycinone and this mixture was designated as the bohemic acid complex ${ }^{4}$. Strain C-36,145 was studied taxonomically and was named Actinosporangium bohemicum sp. nov. This

Table 1. Other actinomycetes producing pyrromycinone glycosides.

\begin{tabular}{|c|c|c|}
\hline Name of organism & Strain No. & Product name \\
\hline $\begin{array}{l}\text { Streptomyces cinereoruber } \\
\text { var. fructofermentans }\end{array}$ & ETH 6143 & Cinerubins $^{5,6)}$ \\
\hline Streptomyces niveoruber & ETH 17860, ETH 17403 & Cinerubins $^{5,6}$, \\
\hline Streptomyces bobiliae & ATCC 3310 & Cinerubin $^{5)}$ \\
\hline Streptomyces sp. & DOA 1205 & Pyrromycin ${ }^{7)}$ \\
\hline Actinomycete & No. A220 & Rutilantin $^{8)}$ \\
\hline Streptomyces ryensis & No. 44, ATCC 29805 & Ryemycins $^{\theta)}$ \\
\hline Streptomyces tauricus & R1A 1417, ATCC 27470 & Tauromycetins ${ }^{10,11)}$ \\
\hline Streptomyces galilaeus & JA 3043 & Galirubins $^{12,13)}$ \\
\hline Streptomyces diastatochromogenes & IMET JA $10081 / 9$ & Trypanomycin $\mathrm{A}_{2}{ }^{14)}$ \\
\hline Streptomyces galilaeus & MA 144-M1, ATCC 31133 & $\begin{array}{l}\text { Cinerubins, pyrromycin, }{ }^{15)} \\
\text { MA-144 group }\end{array}$ \\
\hline Streptomyces sp. & ME 505-HEI, ATCC 31273 & Rhodirubins ${ }^{10)}$ \\
\hline Streptomyces griseorubiginosus & No. 4915 & Cinerubins $^{\theta)}$ \\
\hline
\end{tabular}


organism was deposited in the American Type Culture Collection, Rockville, Md. with the accession number ATCC 31127. Other organisms producing \&-pyrromycinone glycosides are listed in Table 1.

The following anthracyclines were isolated from cultures of strain C-36,145; musettamycin, marcellomycin, rudolphomycin, mimimycin, collinemycin and alcindoromycin. ${ }^{17,18)}$ Their structures were given by DoYLE ${ }^{19)}$ along with other anthracycline oligosaccharides. Among the members of the bohemic acid complex marcellomycin was selected for further study since antitumor activity and preliminary results of toxicological evaluation were encouraging. ${ }^{20)}$ To aid in production of larger amounts of material studies were undertaking to increase the yield of marcellomycin with strain C-36,145.

\section{Materials and Methods}

Strain C-36,145 was isolated from a soil sample from Ontario, Canada in the course of a screening program for discovery of new antitumor agents. Actinosporangium violaceum ATCC 15813, Streptomyces massasporeus ATCC 19785, and Actinopycnidium caerulium ATCC 15812 were obtained from the American Type Culture Collection, Rockville, Maryland. The procedures of SHIRLING and GotTLIEB ${ }^{21)}$ were used to characterize strain C-36,145 for taxonomic studies. The nitrate reduction test was described by GotTLIEB ${ }^{22)}$ and cell wall analysis was performed according to the procedures of YAMA$\mathrm{GUCHI}^{23)}$ and LECHEVALIER and LeCHEVALIER ${ }^{24)}$.

Cinerubin A and cinerubin B were obtained from the National Cancer Institute Bethesda, MD. Procedures for isolation of the bohemic acid complex from cultures of strain C-36,145 and the preparation of marcellomycin, musettamycin, pyrromycin, $\varepsilon$-pyrromycinone and $\eta$-pyrromycinone are described by NetTLETON, et al..$^{4)}$ Sterigmatocystin was prepared from cultures of Aspergillus versicolor M-1073 ${ }^{25)}$.

For maintenance or fermentation studies strain C-36,145 was cultured on agar slant media consisting of either $2 \mathrm{~g}$ glucose, $20 \mathrm{~g}$ oatmeal, $2 \mathrm{~g}$ soy peptone and $20 \mathrm{~g}$ agar made up to one liter with distilled water, or $4 \mathrm{~g}$ glucose, $4 \mathrm{~g}$ yeast extract, $10 \mathrm{~g}$ malt extract and $20 \mathrm{~g}$ agar made up to one liter with distilled water. Slant cultures were incubated at $27^{\circ} \mathrm{C}$ for 144 hours. Spores and mycelium from a slant culture were transferred to $500-\mathrm{ml}$ Erlenmeyer flasks containing $100 \mathrm{ml}$ of sterile vegetative medium. A typical vegetative medium consists of $30 \mathrm{~g}$ glucose, $10 \mathrm{~g}$ soybean flour, $10 \mathrm{~g}$ Pharmamedia (Traders Oil Mill Co., Fort Worth, Texas) and $3 \mathrm{~g} \mathrm{CaCO}_{3}$ made up to one liter with distilled water. The vegetative culture was incubated at $27^{\circ} \mathrm{C}$ for 48 hours on a rotary shaking machine (Gyrotory tier shaker, model G53 New Brunswick Scientific Co., Inc., New Brunswick, New Jersey) describing a 5.1-cm diameter circle. For the fermentation phase four $\mathrm{ml}$ of culture was transferred to a $500-\mathrm{ml}$ flask containing $100 \mathrm{ml}$ of sterile production medium and the culture was incubated on a similar shaker with prescribed experimental conditions.

Strain C-36,145 was cultivated in 14-liter stir-jar fermentors containing ten liters of sterile production medium. Four hundred $\mathrm{ml}$ of vegetative culture was prepared as described previously and was transferred aseptically to the stir-jar fermentor installed in a Fermentor Drive Assembly (Model FS614, New Brunswick Scientific Co., New Brunswick, N.J.). The temperature was maintained at $27^{\circ} \mathrm{C}$, the air flow rate was 6 liters/minute and the agitator was set at $360 \mathrm{rev} /$ minute. Hodag F1 antifoam (Hodag Chemical Corp., Skokie, Illinois) was fed automatically as required to control foaming.

A 48-liter tank fermentor with 37.8 liters of production medium was inoculated with 1.89 liters of vegetative culture agitated with an impeller speed of $300 \mathrm{rev} /$ minute, aerated at 85 liters/minute and incubated at $27^{\circ} \mathrm{C}$. Hodag F1 antifoam was used to control foaming. A 3,800-liter tank fermentor with 3,000 liters of production medium was inoculated with 152 liters of vegetative culture, agitated with an impeller speed of $155 \mathrm{rev} /$ minute, aerated at a rate of 1,400 liters/minute and incubated at $27^{\circ} \mathrm{C}$. Polypropylene glycol was used to control foaming.

Clarified culture samples of strain C-36,145 were prepared for biological testing by centrifugation to remove mycelium. To prepare a mycelial extract, ten $\mathrm{ml}$ sample of culture was centrifuged and the supernatant was replaced with an equal volume of acetone. The mycelium was resuspended, shaken 
for thirty minutes on a reciprocal shaker and centrifuged to remove mycelium. A third procedure, designated a whole culture extract, consisted of extracting a culture sample for 30 minutes with an equal amount of acetone.

Antibiotic activity of culture samples, extracts and isolated bohemic acid components were measured with cylinder type agar diffusion assays. The assay organism, Bacillus subtilis ATCC 6633, was added as a spore suspension to Streptomycin Assay with Yeast Extract (Baltimore Biological Laboratory, Baltimore, Maryland). Assay plates were incubated at $30^{\circ} \mathrm{C}$ for 18 hours. A marcellomycin preparation, found by high pressure liquid chromatography ${ }^{4)}$ to be $98+\%$ pure, was used as a standard and was given an assigned potency of $980 \mathrm{units} / \mathrm{mg}$ for the purpose of microbiological assays. To estimate marcellomycin content C-36,145 culture samples were extracted and the extract was analyzed by high pressure liquid chromatograph. ${ }^{4)}$

The procedure to test for induction of lysogenic Escherichia coli W1709 ( $\lambda$ ) was described by BRADNER, et al. $^{26)}$ Phenobarbitol induced liver microsomes were obtained from Litton Bionetics Laboratory Products, Kensington, Maryland.

Thin-layer chromatography was carried out with $20 \times 20 \mathrm{~cm}$ Uniplates precoated with a $250 \mu \mathrm{m}$ layer of silica gel G (Analtech, Inc., Newark, Delaware). Bioautographs of thin-layer chromatograms with B. subtilis ATCC 6633 were prepared as described in an earlier publication ${ }^{27}$.

Procedures for measurement of antitumor activity against lymphocytic leukemia P388 and L1210 leukemia and Walker 256 carcinosarcoma with test compounds have been described ${ }^{3)}$. To test activity with clarified culture samples $0.5 \mathrm{ml}$ of appropriate dilutions was administered daily for nine days.

\section{Results}

\section{Characterization of Strain C-36,145}

When grown on glucose-asparagine agar, tyrosine agar, yeast extract - malt extract agar and oatmeal agar, strain C-36,145 produces a branched, unfragmented mycelium typical of members of the genus Streptomyces (Fig. 1). On these media there are sporangium-like structures, 8 to $11 \mu \mathrm{m}$ in diameter that are difficult to distinguish from the sporangium of members of the genus Streptosporangium. Electron micrographs of these spore masses failed to reveal a sporangial wall. Spores enclosed in a viscid covering are smooth or warty ellipsoidal and non-motile. These spores masses, therefore, are designated pseudosporangia, which are the predominant spore structure of strain C36,145 . In addition there are sporophores in the form of hooks, loops and irregular open spirals.

Fig. 1. Photomicrograph of strain C-36,145 $(\times 500)$.

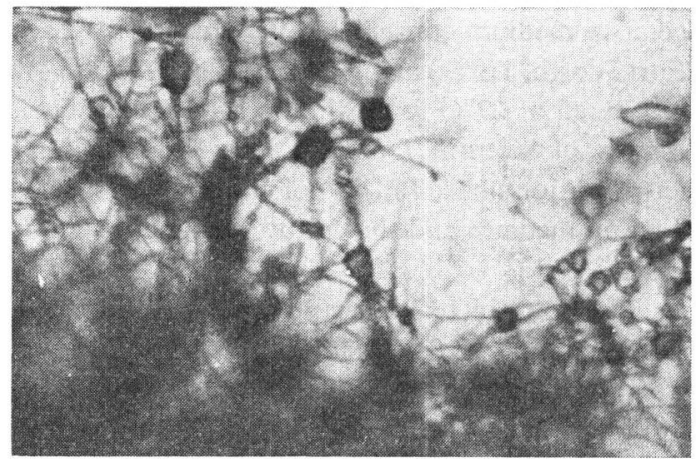

Crude and purified cell wall preparations were found to contain LL-diaminopimelic acid and glycine with two dimensional thin-layer chromatography and liquid chromatography. No diagnostic carbohydrate was found with gas chromatographic analysis trimethylsilylation.

Cultural characteristics are given in Table 2. Aerial mycelium, when fully developed, is grayish pink. In several media the substrate mycelium has $\mathrm{pH}$ indicator pigment that is reddish orange with acid and purple with base. Melanin pigment in tyrosine agar and in peptone-yeast extract-iron agar. Optimal growth temperature on yeast extract-malt extract agar is $28^{\circ} \mathrm{C}$. There is no growth at $10^{\circ} \mathrm{C}$ or $43^{\circ} \mathrm{C}$. Growth is slow at $50^{\circ} \mathrm{C}$ and growth is moderate at $20 \sim 30^{\circ} \mathrm{C}$. 
Table 2. Cultural characteristics of strain C-36,145.

\begin{tabular}{|c|c|c|c|}
\hline Medium & Aerial mycelium & Substrate mycelium & Diffusible pigment \\
\hline Glycerol - asparagine agar & $\begin{array}{l}\text { Moderate, light } \\
\text { gray to pale pink }\end{array}$ & $\begin{array}{l}\text { Rose, orange with } \\
0.05 \mathrm{~N} \mathrm{HCl} \text {, purple } \\
\text { with } 0.05 \mathrm{~N} \mathrm{NaOH}\end{array}$ & Reddish pink \\
\hline $\begin{array}{l}\text { Inorganic salts - starch } \\
\quad \text { agar }\end{array}$ & Scant, grayish pink & $\begin{array}{l}\text { Reddish orange to } \\
\text { deep red, orange } \\
\text { with } 0.05 \mathrm{~N} \mathrm{HCl} \text {, } \\
\text { purple with } 0.05 \mathrm{~N} \\
\mathrm{NaOH}\end{array}$ & $\begin{array}{l}\text { Light orange, partially } \\
\text { light yellow }\end{array}$ \\
\hline Tyrosine agar & Poor, grayish & $\begin{array}{l}\text { Brown to deep purplish } \\
\text { brown }\end{array}$ & Dark brown \\
\hline $\begin{array}{l}\text { Yeast extract - malt } \\
\text { extract agar }\end{array}$ & Moderate, grayish pink & $\begin{array}{l}\text { Deep red, orange tan } \\
\text { with } 0.05 \mathrm{~N} \mathrm{HCl} \\
\text { slightly purple with } \\
0.05 \mathrm{~N} \mathrm{NaOH}\end{array}$ & Light brown \\
\hline Oatmeal agar & Moderate, grayish pink & $\begin{array}{l}\text { Vivid reddish orange, } \\
\text { no change with } \\
0.05 \mathrm{~N} \mathrm{HCl} \text {, purple } \\
\text { with } 0.05 \mathrm{~N} \mathrm{NaOH}\end{array}$ & Vivid orange \\
\hline $\begin{array}{l}\text { Peptone - yeast extract - } \\
\text { iron agar }\end{array}$ & None & Black & Black \\
\hline
\end{tabular}

Table 3. Comparison of strain C-36,145 with possibly related actinomycetes on yeast extract - malt extract agar.

\begin{tabular}{|c|c|c|c|}
\hline Organism & Aerial mycelium & $\begin{array}{l}\text { Substrate } \\
\text { mycelium }\end{array}$ & Diffusible pigment \\
\hline $\begin{array}{l}\text { Actinosporangium violaceum } \\
\text { ATCC } 15813\end{array}$ & White to pale lavender & Amber & Amber \\
\hline $\begin{array}{l}\text { Actinopycnidium caerulium } \\
\text { ATCC } 15812\end{array}$ & White to blue & Reddish blue & Dark blue \\
\hline $\begin{array}{c}\text { Streptomyces massasporeus } \\
\text { ATCC } 19785\end{array}$ & White to purple & Purple & Amber purple \\
\hline Strain C-36,145 & Grayish pink & Deep red & Light brown \\
\hline
\end{tabular}

Carbon sources utilized by strain C-36,145 include L-arabinose, D-xylose, D-ribose, L-rhamnose, Dglucose, D-galactose, D-fructose, D-mannose, sucrose, maltose, lactose, D-melibiose, raffinose, soluble starch, glycerol, inositol and D-mannitol. Strain C-36,145 does not utilize D-arabinose, D-melezitose, cellulose, sorbitol and dulcitol.

Gelatin is liquefied but casein is not hydrolyzed. Nitrate is reduced in CzAPEK's medium. At $0.5 \sim 4.0 \% \mathrm{NaCl}$ growth is moderate while at $8 \% \mathrm{NaCl}$ growth is negligible.

In Table 3 strain C-36,145 is compared with three actinomycete strains showing fused spore masses.

Production of Antitumor and Antibiotic Activity with C-36,145

After isolation from soil, strain C-36,145 was cultured initially in medium 1 (Table 4) for four days in shake-flask culture. Undiluted culture fluid inhibited Walker 256 carcinosarcoma giving a $66 \%$ reduction in tumor growth compared to the control tumor group. With the same culture medium after incubation for five days activity was observed against the P388 tumor system with 1/8 and 1/16 dilutions 
Table 4. Media for production of bohemic acid complex.

\begin{tabular}{|c|c|c|c|}
\hline Medium No. & & Medium No. & \\
\hline $\begin{array}{l}\text { 1. Glucose } \\
\text { Soybean flour } \\
\text { Safflower meal } \\
\mathrm{CaCO}_{3} \\
\text { Distilled water to }\end{array}$ & $\begin{array}{l}30.0 \mathrm{~g} \\
10.0 \mathrm{~g} \\
10.0 \mathrm{~g} \\
3.0 \mathrm{~g} \\
1.0 \text { liter }\end{array}$ & $\begin{array}{l}\text { 6. } \\
\text { Soybean flour } \\
\text { Safflower meal } \\
\mathrm{CaCO}_{3} \\
\text { Distilled water to }\end{array}$ & $\begin{array}{l}50.0 \mathrm{~g} \\
10.0 \mathrm{~g} \\
10.0 \mathrm{~g} \\
3.0 \mathrm{~g} \\
1.0 \text { liter }\end{array}$ \\
\hline $\begin{array}{l}\text { 2. Glucose } \\
\text { Soybean flour } \\
\text { Peanut meal } \\
\mathrm{CaCO}_{3} \\
\text { Distilled water to }\end{array}$ & $\begin{array}{l}30.0 \mathrm{~g} \\
20.0 \mathrm{~g} \\
10.0 \mathrm{~g} \\
3.0 \mathrm{~g} \\
1.0 \text { liter }\end{array}$ & $\begin{array}{l}\text { 7. } \text { Glycerol } \\
\text { Safflower meal } \\
\mathrm{CaCO}_{3} \\
\text { Distilled water to }\end{array}$ & $\begin{array}{l}60.0 \mathrm{ml} \\
20.0 \mathrm{~g} \\
10.0 \mathrm{~g} \\
1.0 \text { liter }\end{array}$ \\
\hline $\begin{array}{l}\text { 3. Glycerol } \\
\text { Soybean flour } \\
\text { Peanut meal } \\
\mathrm{CaCO}_{3} \\
\text { Distilled water to }\end{array}$ & $\begin{array}{l}50.0 \mathrm{ml} \\
20.0 \mathrm{~g} \\
10.0 \mathrm{~g} \\
10.0 \mathrm{~g} \\
1.0 \text { liter }\end{array}$ & $\begin{array}{l}\text { 8. Glycerol } \\
\text { Menhaden fishmeal** } \\
\mathrm{CaCO}_{3} \\
\text { Distilled water to }\end{array}$ & $\begin{array}{l}50.0 \mathrm{ml} \\
20.0 \mathrm{~g} \\
10.0 \mathrm{~g} \\
1.0 \text { liter }\end{array}$ \\
\hline $\begin{array}{l}\text { 4. Glycerol } \\
\text { Soybean flour } \\
\text { Biorex collagen* } \\
\mathrm{CaCO}_{3} \\
\text { Distilled water to }\end{array}$ & $\begin{array}{l}50.0 \mathrm{ml} \\
20.0 \mathrm{~g} \\
10.0 \mathrm{~g} \\
10.0 \mathrm{~g} \\
1.0 \text { liter }\end{array}$ & $\begin{array}{l}\text { 9. Glycerol } \\
\text { Menhaden fishmeal } \\
\text { Linseed meal } \\
\mathrm{CaCO}_{3} \\
\text { Distilled water to }\end{array}$ & $\begin{array}{l}60.0 \mathrm{ml} \\
10.0 \mathrm{~g} \\
10.0 \mathrm{~g} \\
10.0 \mathrm{~g} \\
1.0 \text { liter }\end{array}$ \\
\hline $\begin{array}{l}\text { 5. Glycerol } \\
\text { Safflower meal } \\
\mathrm{CaCO}_{3} \\
\text { Distilled water to }\end{array}$ & $\begin{array}{l}50.0 \mathrm{ml} \\
20.0 \mathrm{~g} \\
10.0 \mathrm{~g} \\
1.0 \text { liter }\end{array}$ & $\begin{array}{l}\text { 10. Glycerol } \\
\text { Cottonseed embryo meal } \\
\mathrm{CaCO}_{3} \\
\text { Tap water to }\end{array}$ & $\begin{array}{l}50.0 \mathrm{ml} \\
20.0 \mathrm{~g} \\
10.0 \mathrm{~g} \\
1.0 \text { liter }\end{array}$ \\
\hline
\end{tabular}

* Dubuque Packing Co., Dubuque, Iowa

** Zapata Haynie Corp., Baltimore, MD.

Table 5. Activity against P388 tumor system in the extracellular fluid of C-36,145 cultures.

\begin{tabular}{|c|c|c|c|c|c|c|c|c|}
\hline \multirow{2}{*}{$\begin{array}{l}\text { Fermentation } \\
\text { vessel }\end{array}$} & \multirow{2}{*}{ Medium* } & \multirow{2}{*}{$\begin{array}{c}\text { Hours } \\
\text { of } \\
\text { incubation }\end{array}$} & \multicolumn{6}{|c|}{$\begin{array}{l}\% \text { Increase in median survival time in days** } \\
(\text { Test group/control group } \times 100)\end{array}$} \\
\hline & & & $1 / 8$ dil & $1 / 16$ dil & $1 / 25 \mathrm{dil}$ & $1 / 50 \mathrm{dil}$ & $1 / 100$ dil & $1 / 200 \mathrm{dil}$ \\
\hline Flask & 1 & 120 & 140 & 135,120 & 120 & 110 & - & - \\
\hline Flask & 2 & 96 & 130 & 130,120 & 125 & 130 & & \\
\hline $\begin{array}{l}\text { Stir-jar } \\
\quad 14 \text { liter } \\
\text { capacity }\end{array}$ & 3 & 162 & - & - & 123 & 135 & 112 & - \\
\hline $\begin{array}{l}\text { Fermentor } \\
48 \text { liter } \\
\text { capacity }\end{array}$ & 4 & 110 & - & - & - & 148,137 & 156 & 96 \\
\hline
\end{tabular}

* See Table 4 for medium composition.

** A value $\geq 125$ is considered significant antitumor activity.

of culture fluid (Table 5). When other media were tested with strain C-36,145 in flasks and tanks, improved production of antitumor activity was obtained (Table 5).

Concomitant with increased antitumor activity, there was an increase in levels of antibiotic activity against Bacillus subtilis ATCC 6633. Both the extracellular fluid and acetone extracts of mycelium inhibited B. subtilis with agar diffusion assays (Table 6). 
Table 6. Distribution of antibiotic activity in extracellular fluid and mycelium of C-36,145 cultures*.

\begin{tabular}{|c|c|c|c|c|c|c|}
\hline \multirow{3}{*}{$\begin{array}{l}\text { Days of } \\
\text { incubation }\end{array}$} & \multicolumn{6}{|c|}{ Antibiotic yield** (Units/ml) } \\
\hline & \multicolumn{2}{|c|}{$210 \mathrm{Rev} / \mathrm{minute} * * *$} & \multicolumn{2}{|c|}{$230 \mathrm{Rev} / \mathrm{minute}$} & \multicolumn{2}{|c|}{$250 \mathrm{Rev} /$ minute } \\
\hline & $\begin{array}{l}\text { Extracellula } \\
\text { fluid }\end{array}$ & $\begin{array}{c}\text { Mycelial } \\
\text { extract }\end{array}$ & $\begin{array}{l}\text { Extracellular } \\
\text { fluid }\end{array}$ & $\begin{array}{c}\text { Mycelial } \\
\text { extract }\end{array}$ & $\begin{array}{l}\text { Extracellular } \\
\text { fluid }\end{array}$ & $\begin{array}{c}\text { Mycelial } \\
\text { extract }\end{array}$ \\
\hline 6 & 22 & 26 & 26 & 18 & 18 & 11 \\
\hline 7 & 35 & 35 & 52 & 42 & 30 & 48 \\
\hline 8 & 33 & 35 & 43 & 35 & 33 & 48 \\
\hline 9 & 50 & 86 & 55 & 105 & 33 & 61 \\
\hline
\end{tabular}

* Production medium 5 (Table 2).

** Agar diffusion assays with Bacillus subtilis ATCC 6633 with marcellomycin as an assay standard $(1,000$ units/mg).

*** Shaker speed.

A mixture of anthracycline antibiotics was isolated from flasks, stir-jars and tanks with strain C-36,145 cultured in media $1 \sim 4$ listed in Table $2^{4)}$.

Among the isolated antibiotics marcellomycin, a pyrromycinone triglycoside, was selected for further study. Therefore, conditions were developed to enhance production of marcellomycin specifically.

Culture extracts were chromatographed with a thin-layer system that separates marcellomycin from some but not all pyrromycinone glycosides (Table 7). High pressure liquid chromatography is suitable to separate marcellomycin from other bohemic acid components and to quantitate marcellomycin content. In a flask culture with me-
Table 7. Chromatography of marcellomycin and related compounds.

\begin{tabular}{|c|c|c|}
\hline Compound & $\begin{array}{c}\mathrm{Rf} \\
\text { value }\end{array}$ & Detection method \\
\hline Cinerubin $\mathbf{B}$ & 0.93 & $\begin{array}{l}\text { Color and bioactive } \\
\text { zone* }\end{array}$ \\
\hline$\eta$-Pyrromycinone & 0.90 & Color \\
\hline$\varepsilon$-Pyrromycinone & 0.77 & Color \\
\hline Cinerubin A & 0.56 & $\begin{array}{l}\text { Color and bioactive } \\
\text { zone }\end{array}$ \\
\hline Marcellomycin & 0.35 & $\begin{array}{l}\text { Color and bioactive } \\
\text { zone }\end{array}$ \\
\hline Pyrromycin & 0.17 & $\begin{array}{l}\text { Color and bioactive } \\
\text { zone }\end{array}$ \\
\hline
\end{tabular}

Silica gel thin-layer plate (Analtech, Inc., Newark, Delaware).

Solvent system: Toluene - ethyl acetate - methanol (3:1:1).

* Bioautograph with Bacillus subtilis ATCC 6633.

Table 8. Induction of lysogenic E. coli W1709 (ג) with anthracyclines.

\begin{tabular}{|c|c|c|c|c|c|c|c|c|c|c|c|c|c|}
\hline \multirow{3}{*}{ Anthracycline } & \multicolumn{13}{|c|}{ Phage count/control* } \\
\hline & \multicolumn{13}{|c|}{ Concentration in the test $(\mu \mathrm{g} / \mathrm{ml})$} \\
\hline & 200 & 100 & 50 & 25 & 12.5 & 6.2 & 3.1 & 1.6 & 0.8 & 0.4 & 0.2 & 0.05 & 0.025 \\
\hline $\begin{array}{l}\text { Bohemic acid } \\
\text { complex }\end{array}$ & 0.2 & 0.3 & 0.2 & 0.8 & 1.1 & 0.9 & 0.8 & & & & & & \\
\hline Pyrromycin & & & 0.4 & 1.0 & 0.9 & 0.8 & 1.0 & & & & & & \\
\hline $\begin{array}{l}\text { Aklavin (1- } \\
\text { deoxypyrromycin) }\end{array}$ & & & 0.5 & 1.2 & 1.1 & 1.2 & 1.1 & & & & & & \\
\hline Aclacinomycin A & & & 0.05 & & 0.1 & & 0.2 & & 0.9 & 1.3 & & & \\
\hline Daunorubicin & & & & & & 18.8 & 11.3 & 6.3 & 3.4 & 2.0 & 1.6 & & \\
\hline Adriamycin & & & & & & 19.3 & 14.1 & 10.0 & 3.0 & 2.1 & 1.4 & & \\
\hline Carminomycin & & & & & & 5.5 & 11.0 & 6.3 & 3.0 & 2.2 & 1.4 & & \\
\hline $\begin{array}{l}\text { Figaroic acid } \\
\text { complex }\end{array}$ & & & & & & & & & 13.9 & & 15.8 & 6.3 & 3.5 \\
\hline
\end{tabular}

* Phage count/control value of 3.0 or greater is significant induction activity. 
dium 7 (Table 4) marcellomycin yield was $127 \mu \mathrm{g} /$ $\mathrm{ml}$ after 240 hours of incubation. On the other hand the addition of $0.005 \mathrm{M}$ potassium phosphate resulted in the production of less than 7 $\mu \mathrm{g} / \mathrm{ml}$.

Glycerol gave superior production of marcellomycin compared to glucose, corn starch or sucrose. Safflower meal, cottonseed embryo meal, linseed meal, Menhaden fishmeal, soybean flour peanut meal and collagen were tested individually as nitrogen sources. Safflower meal, cottonseed embryo meal, linseed meal and Menhaden fishmeal were suitable for marcellomycin production. A combination of fishmeal and

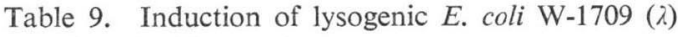
with and without microsomes.

\begin{tabular}{lc|rr}
\hline & & \multicolumn{2}{|c}{$\begin{array}{c}\text { Phage } \\
\text { count/control* }\end{array}$} \\
\cline { 3 - 4 } & & $\begin{array}{c}\text { Without } \\
\text { micro- } \\
\text { somes }\end{array}$ & $\begin{array}{c}\text { With } \\
\text { micro- } \\
\text { somes }\end{array}$ \\
\hline Marcellomycin & $370 \mu \mathrm{g} / \mathrm{ml}$ & 0.4 & 1.2 \\
& 37 & 0.9 & 1.0 \\
Sterigmatocystin & 1,000 & 1.0 & 1.0 \\
Mitomycin C & 100 & 3.7 & 8.5 \\
& 1.0 & 1.1 & 3.0 \\
& 0.1 & 5.0 & 11.0 \\
\hline
\end{tabular}

* A phage count/control value of 3.0 or greater is significant induction activity.

linseed meal gave the best results. With medium 9 (Table 4) marcellomycin was $280 \mu \mathrm{g} / \mathrm{ml}$ in 264 hours of incubation. A yield of $160 \mu \mathrm{g} / \mathrm{ml}$ was obtained at 118 hours in a 37-liter tank fermentation with medium 10. With the same medium the yield was $126 \mu \mathrm{g} / \mathrm{ml}$ at 111 hours in a 3,000-liter tank fermentation.

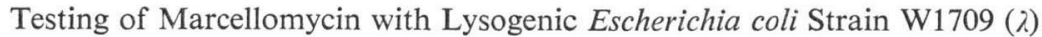

The antitumor activity of marcellomycin has been reported in detail ${ }^{28)}$. Certain other antitumor anthracyclines such as daunomycin, adriamycin and carminomycin I induce lysogenic phage production with Escherichia coli (Table 8). Therefore, marcellomycin was tested with and without treatment with microsomes for the property to induce bacteriophage. In Table 9 the data indicate that marcellomycin

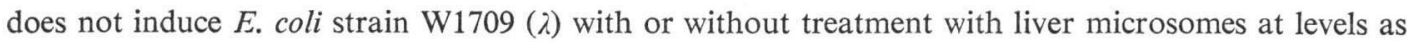
high as $370 \mu \mathrm{g} / \mathrm{ml}$. The activity of sterigmatocystin is enhanced with liver microsomes at $1 \mathrm{mg} / \mathrm{ml}$

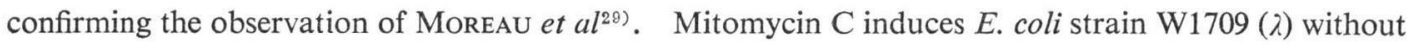
microsomes and activity is reduced with microsomes.

\section{Discussion}

In 1961 the genus Actinosporangium was proposed by KRASIL'NIKOv and TsI-SHEN ${ }^{30)}$ to include those actinomycetes having sporangia consisting of mucous masses formed by the fusion of several sporophores. These investigators designated strain 3810 which exhibits such sporangia as Actinosporangium violaceus and placed this species in the family Actinoplanaceae. Extensive examination of these spore masses failed to indicate a sporangial wall. The cell wall analysis of this strain was found to be typical of the genus Streptomyces having LL-diaminopimelic acid and no DD-diaminopimelic acid. ${ }^{23)}$ Additional members of the genus Actinosporangium were described ${ }^{31,32)}$ but cell wall analyses have not been reported. Actinosporangium has been listed as a valid genus name ${ }^{33)}$. In view of the cell wall analysis of strain 3810 it would be more appropriate to place the genus Actinosporangium in the family Streptomycetaceae rather than Actinoplanaceae.

DNA-DNA homology studies indicate that Actinosporangium violaceum DSM 43159 is closely related to members of the genus Streptomyces. ${ }^{34)}$ The usefulness of maintaining a separate genus $A c$ tinosporangium will be determined with the examination of more strains having morphology similar to strains 3810 and C-36,145.

Strain 3810 does not produce diffusible pigments in diagnostic media while strain C-36,145 produces 
reddish orange diffusible pigments of the anthracycline type.

HUSSEIN and KRASIL'NIKOV in $1969^{32}$ ) described 33 actinomycete strains having smooth spores enclosed in mucous sporangia without a sporangial membrane. Each of these strains was distributed among four species, Actinosporangium calcenogenum, A. granulosum, A. violatum and A. aurantiacus, on the basis of the color of the substrate mycelium. All these strains were reported to have beige or dark beige aerial mycelium. On the other hand strain C-36,145 has grayish pink aerial mycelium.

Streptomyces massasporeus strain 602 ATCC 15813 ${ }^{35,36)}$ and Actinopycnidium caerulium ATCC $15812^{37,38)}$ reported to show fused spore masses were different from C-36,145 on yeast extract - malt extract agar in regard to color of aerial and substrate mycelium (Table 3).

Since strain C-36,145 shows significant differences from those organisms previously described it is placed in a new species designated Actinosporangium bohemicum.

Phosphate stimulates production of cinerubins with Streptomyces griseorubiginosus ${ }^{\vartheta)}$ and daunomycinone glycosides with Streptomyces sp. $^{39)}$ but inhibits marcellomycin production. With strain C36,145 phosphate appears to enhance other bohemic acid components possibly cinerubin A and $\mathrm{B}$ at the expense of marcellomycin and rudolphomycin. Since glucose and phosphate are commonly used in production media, this practice might explain why marcellomycin was not observed by other investigators examining cinerubin cultures with the exception of Streptomyces galilaeus MA 144-M1 ATCC $31133^{15)}$.

Marcellomycin and other components in the bohemic acid complex do not induce E. coli strain

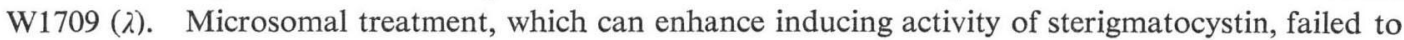
have such an effect on marcellomycin. Conversely, daunomycin, adriamycin, carminomycin and the mixture of carminomycinone glycosides called figaroic acid complex ${ }^{40)}$ were effective inducers without microsomal treatment (Table 8). Other anthracyclines such as aklavinone glycosides, nogalomycin type, rhodomycin type and pyrromycinone glycosides also fail to induce E. coli strain W1709 ( $\lambda$ ). Aclacinomycin $^{41)}$ and marcellomycin ${ }^{42)}$ are not mutagenic with Salmonella typhimurium tests while adriamycin is mutagenic ${ }^{41)}$. All these findings are consistent with differing actions on nucleic acid synthesis. For example, adriamycin is more active than aclacinomycin in causing DNA cleavage ${ }^{43}$ ) whereas aclacinomycin and several pyrromycinone oligosaccharides cause greater inhibition of RNA synthesis, particularly nucleolar RNA synthesis, than adriamycin ${ }^{44)}$.

The fact that marcellomycin had antitumor effects in several experimental systems, had a possibly more favorable toxicity profile as suggested by preliminary studies ${ }^{20,45)}$ and a differing mechanism of action compared to adriamycin and daunomycin has lead to clinical trials of marcellomycin which are now underway.

\section{Acknowledgements}

We thank Drs. T. W. Doyle and D. E. Nettleton, Jr. for analytical and support. Dr. R. P. Elander and other members of Bristol-Myers Co. Industrial Div. are gratefully acknowledged for tank scale-up assistance. Research studies in this report were supported in part by Contract Nos. 1-CM-77147 and 1-CM-07299 from the Division of Cancer Treatment, National Cancer Institute, National Institutes of Health, Department of Health, Education and Welfare, U.S.A.

\section{References}

1) Talalay, P.; G. M. V. Takano \& C. Huggins: Studies on the Walker tumor. I. Standardization of the growth of a transplantable tumor. Cancer Res. 12: 834 837, 1952

2) Bradner, W. T. \& D. J. Hutchinson: Neocarzinostatin (NSC-69856): An antitumor antibiotic effective against ascitic leukemia L-1210 in mice. Cancer Chemother. Rep. 50: 79 84, 1966

3) Geran, R. I.; N. H. Greenberg, M. M. MacDonald, A. M. Schumacher \& B. J. Abbott: Protocols for screening chemical agents and natural products against tumors and other biological systems (3rd edition). Cancer Chemother. Rep. Part 3, 3: 1 103, 1972

4) Nettleton, D. E., Jr.; W. T. Bradner, J. A. Bush, A. B. Coon, J. E. Moseley, R. W. Myllymaki, F. A. o'Herron, R. H. Schreiber \& A. L. Vulcano: New antitumor antibiotics: Musettamycin and marcello- 
mycin from bohemic acid complex. J. Antibiotics 30: 525 529, 1977

5) Corbaz, R.; L. Ettlinger, W. Keller-Schierlein \& H. ZÄhner: Zur Systematik der Actinomyceten. 1. Über Streptomyceten mit rhodomycinartigen Pigmenten. Arch. Mikrobiol. 25: 325 332, 1957

6) Ettlinger, L.; E. Gäumann, R. Hütter, W. Keller-Schierlein, F. Kradolfer, L. Neipp, V. Prelog, P. Reusser \& H. ZÄHNER: Stoffwechselprodukte von Actinomyceten. XVI. Cinerubine. Chem. Ber. 92: $1867 \sim 1879,1959$

7) Brockmann, H. \& W. Lenk: Über Actinomycetenfarbstoffe. VI. Pyrromycinone. Chem. Ber. 92: 1880 1903, 1959

8) Asheshov, I. N. \& J. J. Gordon: Rutilantin: an antibiotic substance with antiphage activity. Biochem. J. $31: 101 \sim 104,1961$

9) David, L.; M. Duteurtre, A. Kergomard, G. Kergomard \& E. Scanzi: Production of cinerubins by a Streptomyces griseorubiginosus strain. J. Antibiotics 33: 49 53, 1980

10) Ivanitskaya, L. P.; G. D. Upiter, M. A. Sveshnikova \& G. F. Gauze: Systematic position, variation and antibiotic properties of tauromycetin producing organism. Antibiotiki 11: 973 976, 1966

11) Shirling, E. B. \& D. Gottlieb: Cooperative description of type strains of Streptomyces. V. Additional descriptions. Int. J. Syst. Bacteriol. 22: $265 \sim 394,1972$

12) Bradler, G.; K. ECKardt \& R. FüGner: Zur Characterisierung des Streptomyces-Stammes JA 3043 und Gewinnung von Galirubin und Galirubinonen. Zeit. Allg. Mikrobiol. 6: 361 365, 1966

13) Královcova, E.; J. Tax, M. Blumauerová \& Z. VaneK: Bewerlung der Produktion von Glycosiden des $\varepsilon$ Pyrromycinons (Galirubine) bei der Züchtung des Stammes Streptomyces galilaeus. Zeit. Allg. Mikrobiol. 17: $47 \sim 50,1977$

14) Fleck, W.; D. Strauss, C. Schönfeld, W. Jungstand, C. Seeber \& H. Prauser: Screening, fermentation, isolation and characterization of trypanomycin, a new antibiotic. Antimicr. Agents Chemother. 1: 385 391,1972

15) Oki, T.; N. Shibamoto, Y. Matsuzawa, T. Ogasawara, A. Yoshimoto, I. Kitamura, T. Inui, H. NagaNAWA, T. TAKeuchi \& H. UmezaWA. Production of nineteen anthracyclic compounds by Streptomyces galilaeus MA 144-M1. J. Antibiotics 30: 683 687, 1977

16) Kitamura, I.; N. Shibamoto, T. Oki, T. Inui, H. Naganawa, M. Ishizuka, T. Masuda, T. Takeuchi \& H. Umezawa: New anthracyline antibiotics, rhodirubins. J. Antibiotics 30: 616 618, 1977

17) Doyle, T. W.; D. E. Nettleton, Jr., R. E. Grulich, D. M. Balitz, D. L. Johnson \& A. L. Vulcano: Antitumor agent from the bohemic acid complex. 4. Structure of rudolphomycin, mimimycin, collinemycin and alcindoromycin. J. Am. Chem. Soc. 101: 7041 7049, 1979

18) Nettleton, D. E., Jr.; D. M. Balitz, T. W. Doyle, W. T. Bradner, D. L. Johnson, F. A. O’Herron, R. W. Schreiber, A. B. Coon, J. E. Moseley \& R. W. Myllymaki: Antitumor agents from bohemic acid complex. III. The isolation of marcellomycin, musettamycin, rudolphomycin, mimimycin, collinemycin, alcindoromycin, and bohemamine. J. Nat. Prod. 43: 242 258, 1980

19) Doyle, T. W.: Anthracycline oligosaccharides. In Anthracylines: Current Status and New Developments. pp. $27 \sim 41$, Ed. by S. T. Crooke and S. D. ReIch, Academic Press, New York, 1980

20) Reich, S. D.; W. T. Bradner, W. C. Rose, J. E. Schurig, H. Madissoo, D. F. Johnson, V. H. DuVernay \& S. T. Crooke: Marcellomycin. In Anthracyclines: Current Status and New Developments. pp. 343 364, Ed. by S. T. Crooke and S. D. Reich, Academic Press, New York, 1980

21) Shirling, E. B. \& D. Gottlieb: Methods for characterization of Streptomyces species. Int. J. Syst. Bacteriol. 16: 313 340, 1966

22) Gotrlieb, D.: An evaluation of criteria and procedures used in the description and characterization of the Streptomycetes. Appl. Microbiol. 9: 55 65, 1961

23) Yamaguchi, T.: Comparison of the cell-wall composition of morphologically distinct actinomycetes. J. Bacteriol. 89: 444 453, 1965

24) Lechevalier, M. P. \& H. Lechevalier: Chemical composition as a criterion in the classification of aerobic actinomycetes. Int. J. Syst. Bacteriol. 20: 435 443, 1970

25) Bradner, W. T.; J. A. Bush, R. W. Myllymaki, D. E. Nettleton, Jr. \& F. A. O’Herron: Fermentation, isolation and antitumor activity of sterigmatocystins. Antimicrob. Agents Chemother. 8: 159 163, 1975

26) Bradner, W. T.; B. Heinemann \& A. Gourevitch: Hedamycin, a new antitumor antibiotic. II. Biological properties. Antimicrob. Agents Chemother. -1966: 613 618, 1967

27) Bush, J. A.; C. S. Cassidy, K. E. Crook, Jr. \& L. B. German: Kundrymycin, a new tumor-inhibitory antibiotic. I. Culture taxonomy, fermentation and production. J. Antibiotics 24: 143 148, 1971

28) Bradner, W. T. \& M. Misiek: Bohemic acid complex. Biological characterization of the antibiotics, musettamycin and marcellomycin. J. Antibiotics 30: 519 522, 1977 
29) Moreau, P.; A. Bailone \& R. Devoret: Prophage $\lambda$ induction in Escherichia coli K12 env A uvr B: A highly sensitive test for potential carcinogens. Proc. Natl. Acad. Sci. USA 73: 3700 3704, 1976

30) Krasil'nikov, N. A. \& Y. Tsi-Shen: Actinosporangium-a new genus of the Actinoplanaceae family. Izv. Akad. Nauk SSSR, Ser. Biol. 1: 113 116, 1961

31) Hussein, A. \& N. A. Krasil'Nikov: Four new species of actinomycetes in the genus Actinosporangium. Microbiology 38: 885 891, 1969

32) Hussein, A. \& N. A. Krasil'nikov: Slime actinomycetes from Egyptian soils. Microbiology 38: 748 753, 1969

33) Skerman, V. B. D.; V. McGowan \& P. H. A. Sneath: Approved lists of bacterial names. Int. J. Syst. Bacteriol. 30: 225 420, 1980

34) Stackebrandt, E.; B. Wunner-Fussl, V. J. Fowler \& K. H. Schleifer: Deoxyribonucleic acid homologies and ribosomal ribonucleic acid similarities among spore-forming members of the order Actinomycetales. Int. J. Syst. Bacteriol. 31: 420 431, 1981

35) Shinobu, R. \& M. Kawato: On Streptomyces massasporeus nov. sp. Bot. Mag. Tokyo 72: 284 288, 1959

36) Shirling, E. B. \& D. Gottlieb: Cooperative description of type cultures of Streptomyces. II. Species descriptions from first study. Int. J. Syst. Bacteriol. 18: 69 189, 1968

37) Krasil'Nikov, N. A.: A new genus of ray fungus-Actinopycnidium n. gen. of family Actinomycetaceae. Mikrobiologiya 31: 250 253, 1962

38) Williams, S. T.: Further investigations of actinomycetes by scanning electron microscopy. J. Gen. Microbiol. 62: $67 \sim 73,1970$

39) McGuire, J. C.; B. K. Hamilton \& R. J. White: Approaches to development of the daunorubicin fermentation. Proc. Biochem. 14: 2 5, 1979

40) Bradner, W. T.; J. A. Bush \& D. E. Nettleton, Jr.: Antibiotic complex. U. S. Patent 4,112,071, Sept. 5, 1978

41) Umezawa, K.; M. Sawamura, T. Matsushima \& T. Sugimura: Mutagenicity of aclacinomycin A and daunomycin derivatives. Cancer Res. 38: 1782 1784, 1978

42) Bradner, W.T.: New prescreens for antitumor antibiotics. Antibiotics and Chemotherapy, Vol. 23, pp. $4 \sim 11$, Ed. by H. Schönfeld, R. W. Brockman \& F. E. Hahn, S. Karger, Basel, 1978

43) SomeyA, A. \& N. TANAKA: DNA strand scission induced by adriamycin and aclacinomycin A. J. Antibiotics 32: 839 845, 1979

44) Duvernay, V. H.; S. Mong \& S. T. Crooke. Molecular pharmacology of anthracyclines: demonstration of multiple mechanistic classes of anthracyclines. In Anthracyclines: Current Status and New Developments. pp. $61 \sim 123$, Ed. by S. T. Crooke \& S. D. ReICH, Academic Press, New York, 1980

45) Schurig, J. E.; W. T. Bradner, J. B. Huftalen \& G. J. Doyle: Screening anthracyclines for side effects in mice. In Anthracylines: Current Status and New Developments. pp. $141 \sim 149$, Ed. by S. T. CROOKE \& S. D. Reich, Academic Press, New York, 1980 